\title{
Development of an experimental model of endometriosis in rats
}

\section{Desenvolvimento de modelo experimental de endometriose em ratas}

\author{
Vivian Ferreira do Amaral ${ }^{1}$; Eduardo Andreazza Dal lago²; William Kondo, ACBC-PR³; luiz César Guarita-Souza ${ }^{4}$; Júlio César
} FRANCISCO ${ }^{5}$

\author{
A B S T R A C T
}

\begin{abstract}
Objective: To develop an experimental model of endometriosis in rats. Methods: Thirty adult female Wistar rats were used. The surgical technique consisted of median laparotomy with identification of the bicornuate uterus and resection of a 2-cm segment of the right uterine horn. A $0.25 \mathrm{~cm}^{2}$ flap was removed from that structure and sutured to the abdominal wall with the endometrial side facing the peritoneal cavity. The rats were randomly divided into two groups according to the reoperation date: group 1 ( $n=15)$ was reoperated in 30 days, and group $2(n=15)$, in 60 days. On the occasion of the second laparotomy, the implants were evaluated macroscopically, resected and referred for microscopic analysis with hematoxylin-eosin and immunohistochemical staining (HEMA, AE1 and AE2). Results: The implants developed in $83.3 \%$ of group 1 and $71.4 \%$ of group 2. There was no statistically significant difference between the weights of the animals in the two groups. No statistically significant difference was found in the surface area of the induced lesions: in group 1, the mean was $0.37 \mathrm{~cm}^{2}$ and in group $2,0.25 \mathrm{~cm}^{2}$. According to Keenan's semiquantitative histological classification (based on the preservation status of the epithelial layer of the endometrium), the mean for group 1 was 1.9 and for group 2, 2.4. Conclusion: The technique used for inducing the development of endometriosis in rats was satisfactory.
\end{abstract}

Key words: Endometriosis. Rats. Models, animal. Endometrium.

\section{INTRODUCTION}

E ndometriosis is a chronic condition characterized by the presence of endometrial tissue (glands and/or stroma) outside the uterine cavity ${ }^{1}$. These ectopic deposits of endometrium are more commonly found in the ovaries, peritoneum, uterosacral ligaments and rectovaginal pouch, but extrapelvic implants may also be present ${ }^{2}$.

The prevalence in women of reproductive age is estimated to be $10 \%^{3}$. In women presenting with chronic pelvic pain, that prevalence may reach up to $82 \% 4,5$, and in those undergoing investigation for infertility, between $20 \%$ and $50 \%$ 3,6-8.

Several theories have been proposed to explain the pathogenesis of this disease ${ }^{9}$. Among them, the most relevant are the retrograde menstruation theory (implantation theory or Sampson's theory) ${ }^{10}$, the celomic metaplasia theory ${ }^{11-13}$ and the embryonic remnants theory ${ }^{14,15}$. However, none of them sufficed to elucidate the etiopathogeny of the disease. There is a current trend to associate those theories with each other and with aspects such as immunological, hormonal, genetic and environmental factors.
Endometriosis usually appears in the reproductive years, when the lesions are stimulated by ovarian hormones. A significant number of women remains asymptomatic. In those who are symptomatic, the events of pain tend to be more intense in the premenstrual period, improving after cessation of menstruation. Pelvic pain as dysmenorrhea is the most common symptom, and does not correlate with the visually assessed degree of endometriosis ${ }^{16}$ nor with the depth of tissue infiltration ${ }^{17,18}$. Other symptoms that may be present are lumbar pain, dyschezia, pain during micturition and dyspareunia. The latter, when deep, may be the result of fibrosis in the uterosacral ligaments, nodularity of the rectovaginal septum, obliteration of the pouch and/or uterine retroversion. In addition, endometriosis is associated with infertility as a result of adhesions that distort the pelvic anatomy and impair ovum release and capture. However, tubal distortion is not the only cause of infertility, since endometriosis patients seem to have worse ovarian reserve with lower oocyte and embryo quality ${ }^{2}$.

The gold standard for the diagnosis of endometriosis is direct visualization of the endometrial lesions via laparoscopy, accompanied by histological confirmation of the presence of at least two of the following findings: 
macrophages containing hemosiderin or endometrial epithelium, glands, or stroma ${ }^{19}$.

The ideal treatment for this disease is yet to be discovered ${ }^{20}$. The available options are based on drugs, surgery and on the association of both. The therapeutic modality to be adopted is dependent on factors such as the stage of the disease, symptomatology, the patient's age and the desire for a future pregnancy.

The fact that endometriosis requires an invasive method for diagnosis hampers or even prevents the undertaking of controlled studies on the response of endometriosis implants to the various drugs ${ }^{21}$. Therefore, a good animal experimental model is required in order to elucidate the disease mechanism and test new therapeutic drugs. However, endometriosis occurs spontaneously only in primates, which are too costly for experimental use ${ }^{22}$. Consequently, experimental models have been surgically produced in small animals such as rabbits, rats and mice ${ }^{23-28}$. The murine model proposed by Jones ${ }^{29}$ in 1984 is the most widely employed, since the operative technique is simple and most implants are successful, that is, induction of endometriosis is effective and reproducible ${ }^{21}$.

The objective of this study is the development of an experimental model of endometriosis in rats according to the technique proposed by Jones ${ }^{29}$.

\section{METHODS}

The study was previously approved by Opinion 80/07 of the Animal Research Ethics Committee of the Pontifícia Universidade Católica do Paraná (PUC-PR) and followed the guidelines of the Colégio Brasileiro de Experimentação Animal (Brazilian College of Animal Experimentation, COBEA).

Female Wistar rats (Rattus norvegicus albinus), adult and virgin, were kept in appropriate cages with five animals each, under controlled temperature, humidity and environment luminosity. They received water and chow ad libitum. After a three-day acclimation period, the surgical procedure for induction of endometriosis was performed.

Over the period from December 2007 through January 2008, 30 female rats were operated on at the Operative Technique and Experimental Surgery Laboratory of PUCPR. A preoperative fast was established for the 12 hours preceding the operation.

Prior to anesthesia, the animals were weighed for anesthetic dose calculation. Anesthesia was achieved with an intraperitoneal injection of $0.2 \mathrm{~mL} / 100 \mathrm{~g}$ body weight of the combination of $1 \mathrm{~mL}$ ketamine $(50 \mathrm{mg} / \mathrm{mL})$ and $1 \mathrm{~mL}$ xylazine $(20 \mathrm{mg} / \mathrm{mL})$.

Following anesthesia, electric hair clippers were used to remove the hair from the abdominal wall of the animals. The rats were then tied to the surgery board in supine, with the limbs in abduction, and routine antisepsis was performed. The operation was initiated with a $3-\mathrm{cm}$ median incision $2 \mathrm{~cm}$ above the pubis.
The procedure for inducing the development of an endometriotic lesion was carried out based on a published study $^{29}$. The bicornuate uterus was identified and the blood vessels of the left uterine horn were ligated with 3-0 vicryl (Figures 1 and 2). A 2-cm segment of the middle-third of the left uterine horn was then resected. This segment was immersed in saline $0.9 \%$ at $4^{\circ} \mathrm{C}$ for approximately two minutes, and then incised longitudinally, originating a flap, from which a $5 \times 5 \mathrm{~mm}\left(0.25 \mathrm{~cm}^{2}\right)$ section was removed. This section was sutured to the abdominal wall on the right flank of the rat using two simple 6-0 mononylon stitches, next to a blood vessel, and in such a way that the endometrial side was always facing the abdominal cavity (Figure 3). After ensuring hemostasis in the left uterine horn and the cleaning of the abdominal cavity, the abdominal wall was closed in layers. The musculoaponeurotic layer was sutured with continuous 3-0 vicryl suture and the skin with continuous 3-0 mononylon.

After the operation, the animals were taken to the PUC-PR breeding colony, where they stayed until reoperation date.

\section{Reoperation and histological analysis}

Reoperation was performed one month (Group 1) and two months (Group 2) after the first operation in

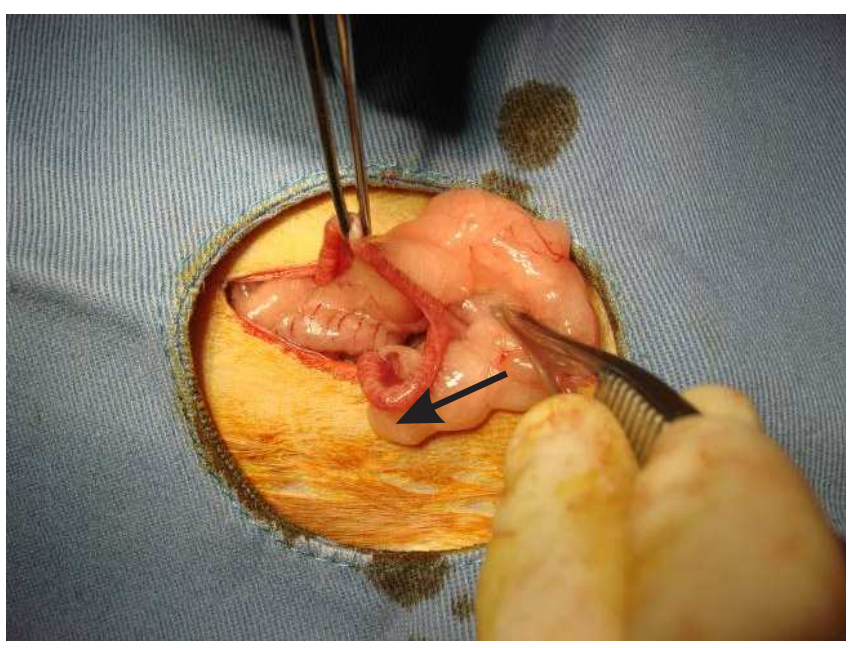

Figure 1 - Typical rat bicornuate uterus.

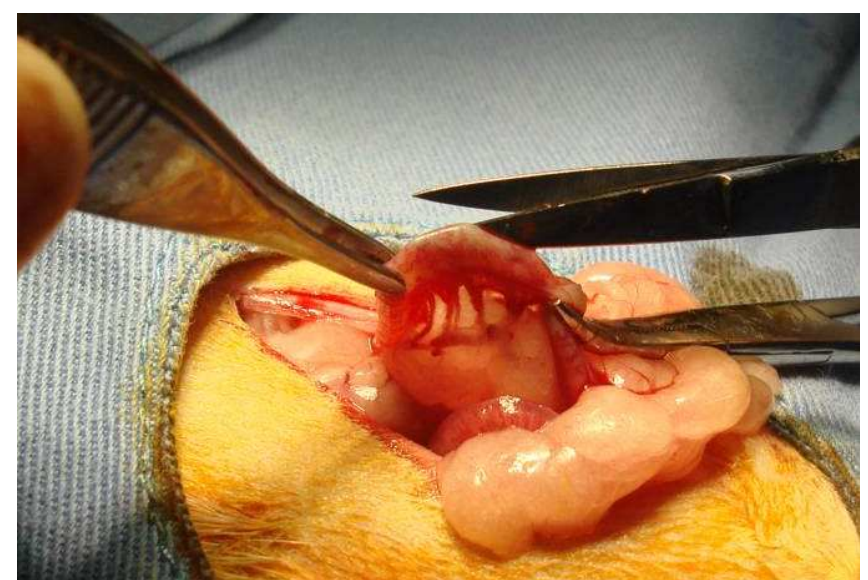

Figure 2 - Resection of a segment of the uterine horn. 
order to confirm the growth of the lesion macroscopically and to collect samples for histological analysis. After opening the abdominal wall, the lesions were identified and measurements were taken. Subsequently, those implants were resected (Figure 4), fixed in 10\% formalin and processed for paraffin embedding and histological analysis at the Experimental Pathology Laboratory of PUC-PR.

The slides were stained with HE (hematoxylineosin) and analyzed under a light microscope (Olympus; Melville, NY) to confirm the presence of endometrial tissue. The manual tissue microarray technique was performed using the paraffin blocks. The prepared slides were analyzed by light microscopy to locate regions with the presence of endometrium, which were marked with a pen. Through the mirror system, the marked slide was used to pinpoint the region in the paraffin block, which was marked as well. A 2-mm skin biopsy punch was used to extract the cores from the paraffin block. In order to assist in locating the

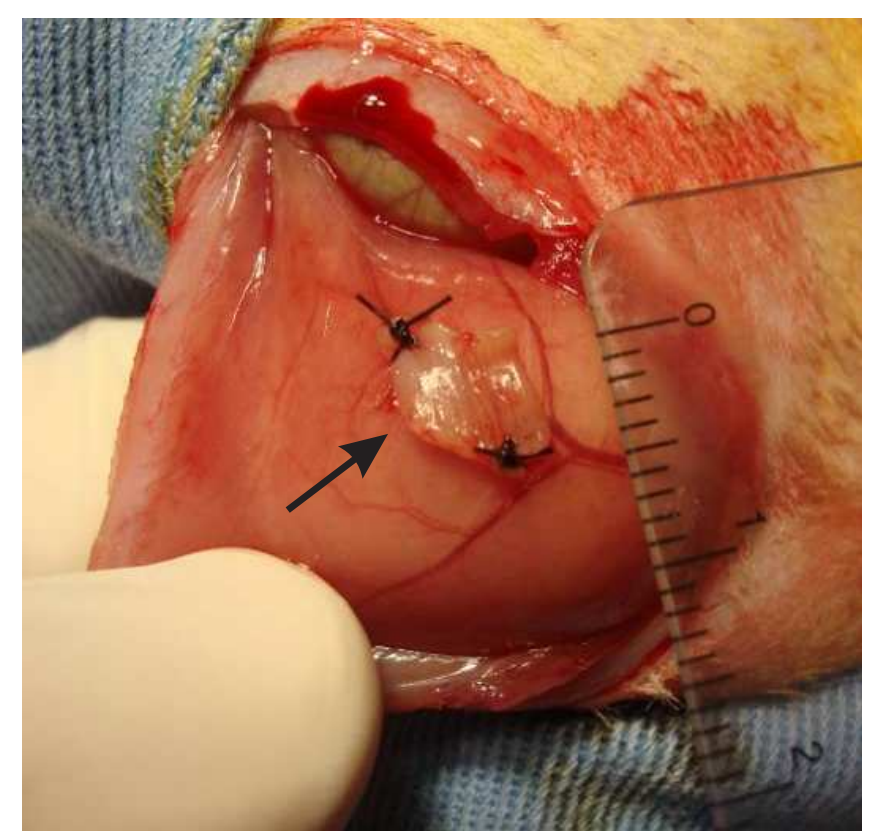

Figure 3 - Endometrium implant on the abdominal wall.

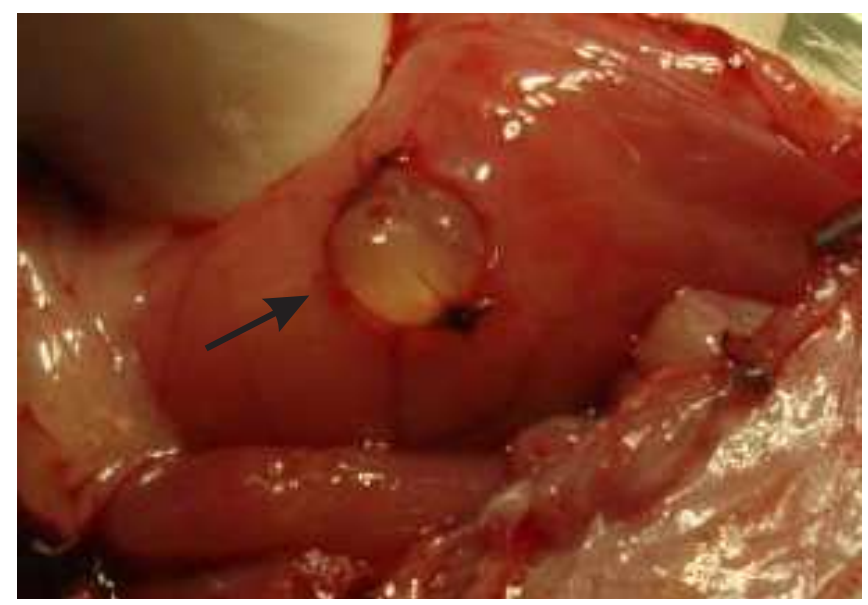

Figure 4 - Endometrium implant in group 2. material, a map was made. After the removal of the sections, histological slides were prepared from all blocks using the markers HEMA, AE1 and AE2.

The persistence of epithelial cells in the implants was evaluated according to the classification proposed by Keenan ${ }^{30}$, as follows: well-preserved epithelial layer = score 3, moderately preserved epithelium with leukocyte infiltrate $=$ score 2 , poorly-preserved epithelium (occasional epithelial cells only) = score 1, no epithelium = score zero.

The results obtained in the study were expressed as means, medians, minimum and maximum values, and standard deviation, or as frequencies and percentages. Student's $t$ test for independent samples or the nonparametric Mann-Whitney test were used, as appropriate, for the inter-group comparison regarding the quantitative variables. The groups were compared through Fisher's exact test for the dichotomous nominal variables. Values of $p<0.05$ indicated statistical significance.

\section{RESULTS}

Out of the 30 rats operated on, 4 died in the period between the first and the second operation: three in Group 1 and one in Group 2. Upon reoperation, the implantation sites of endometrial tissue were evaluated macroscopically. In four animals, it was not possible to identify that tissue (two animals in each group). In addition, an abscess was found at the implant site in two rats of Group 2. These two animals were counted as not having developed the lesion. The overall success rate was $76.9 \%$ (20/26) $-83.3 \%$ in group $1(10 / 12)$ and $71.4 \%$ in Group 2 $(10 / 14)$.

There was no statistically significant difference between the mean weights of the animals in groups 1 and $2(271.6 \mathrm{~g}$ and $260 \mathrm{~g}$, respectively; $\mathrm{p}=0.147$ ).

No statistically significant difference was found between the groups regarding the variables length, width and surface area of the surgically-induced endometriosis lesions (Table 1).

All implants were submitted to histological analysis; there was no difference between the two groups (Figure 5).

\section{DISCUSSION}

The experimental models of endometriosis surgically produced in small animals are classified into two types: homologous and heterologous. In the homologous model, the endometrium is obtained from the animal's uterus and sutured or dispersed in the peritoneal cavity. In the heterologous model, human endometrial explants are injected intraperitoneally or subcutaneously into immunocompromised rats. In both cases, endometriosislike lesions, histologically identified, are induced in the animals. 
Table 1 - Comparison of measures of lenght, width and area of the groups.

\begin{tabular}{lcccccccc}
\hline Variable & Group & $\mathbf{n}$ & Mean & Median & Minimum & Maximum & Standard deviation & $p^{*}$ value \\
\hline \multirow{2}{*}{ Length } & 1 & 10 & 0,72 & 0,6 & 0,4 & 1,1 & 0,27 & \\
\multirow{2}{*}{ Width } & 2 & 10 & 0,57 & 0,5 & 0,3 & 1 & 0,22 & 0,190 \\
\multirow{2}{*}{ Area } & 1 & 10 & 0,51 & 0,5 & 0,3 & 0,8 & 0,15 & \\
& 2 & 10 & 0,41 & 0,3 & 0,2 & 1 & 0,25 & 0,165 \\
& 1 & 10 & 0,37 & 0,32 & 0,15 & 0,77 & 0,18 & \\
& 2 & 10 & 0,25 & 0,15 & 0,06 & 0,80 & 0,22 & 0,075 \\
\hline
\end{tabular}

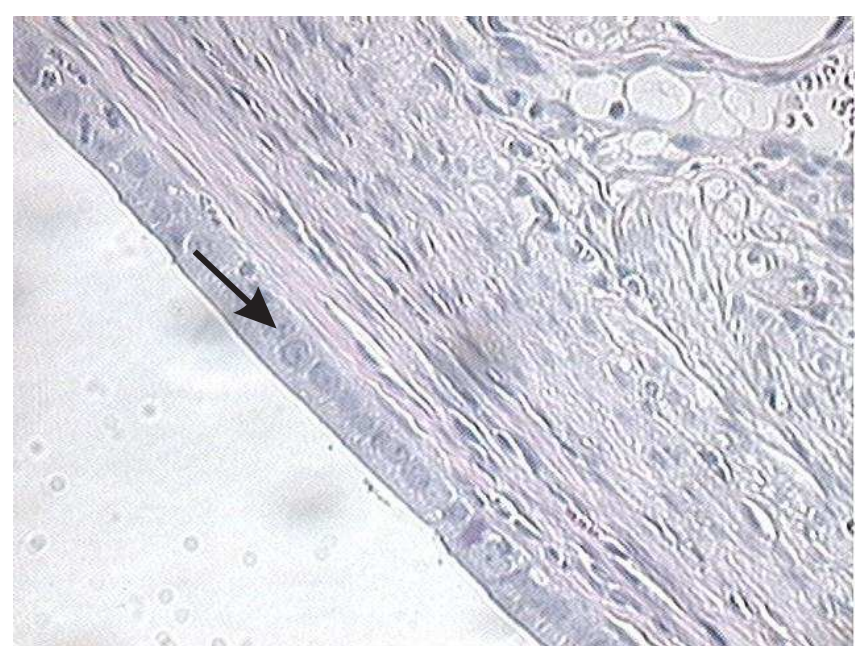

Figure 5 - $\quad$ Photomicrograph of a well-preserved epithelial cell (animal from Group 2).

Although using models in non-primates is advantageous because they can develop endometriosis-like lesions and for the low cost, these models have various disadvantages. Comparisons are made difficult by the large number of experimental techniques used and by the wide phylogenetic gap between non-primates and humans. More importantly, non-primates have no menstrual cycles and do not develop spontaneous endometriosis. The rat ovulates spontaneously, but the luteal phase is shorter than in humans. The endometriotic lesions produced in rats are different from those in humans, as the former consist of cysts containing a clear serous fluid with no evidence of neoangiogenesis ${ }^{31}$. In spite of these differences, experimental models are very important for the study of the disease and the testing of new therapeutic modalities.

The choice for the experimental model with rats was based on the low cost, previous background from the literature and the resistance of these animals to infections. The technique described by Jones in $1984^{29}$ in a murine model is the most widely used in the world literature, since the surgical procedure is simple and most implants develop successfully, i.e., endometriosis induction is effective and reproducible ${ }^{21,23}$. It is possible, therefore, to standardize implant size, which is indispensable to evaluate the efficacy of new therapeutic drugs.

In the present study, 4 out of the 30 rats submitted to the procedure were excluded, since they died between the first and the second operations, leaving 26 animals for the final analysis. The success rate in the macroscopic development of endometriosis lesions was $76.9 \%$ (20 out of 26). Sometimes the lesions are not clear enough to be distinguished from the adjacent normal tissue. This makes it difficult to determine the surface area and weight of the lesions, essential variables in the experiment ${ }^{32}$.

The main parameter analyzed in the present study was the surface area of the implants. Contrary to most studies, which show stability or growth of the lesions in the interval between the second and third operations ${ }^{22}$, regression of the implant area $\left(0.37 \mathrm{~cm}^{2}\right.$ to $\left.0,25 \mathrm{~cm}^{2}\right)$ was found, yet with no statistically significant difference.

According to the anatomopathological classification proposed by Keenan ${ }^{30}$, eight animals had a score of zero. Conceptually, the lesions in those animals could not be regarded as endometriosis, as the disease is characterized by the presence of glandular and/or stromal tissue outside the uterine cavity. However, if the animals with a score of zero were included, the mean of scores would be 1.3 and 1.4 in Groups 1 and 2, respectively, which is comparable to the mean of the control group scores in Keenan's study ${ }^{30}$.

Although the expression "experimental endometriosis" is used in the literature, strictly speaking, the present study involved fragments of normal endometrium on the abdominal wall of healthy rats. The actual correlation of these foci of endometrial tissue with human endometriosis is unknown ${ }^{33}$. Nevertheless, the widespread utilization of research protocols with experimental endometriosis in animal models is justified in that a thorough evaluation of the implants in humans is not feasible, since the diagnostic methods are invasive (videolaparoscopy or laparotomy).

The development of experimental endometriosis in rats according to Jones's model was satisfactory. 


\begin{abstract}
Objetivo: Desenvolver um modelo de endometriose experimental em ratas. Método: Foram utilizadas 30 ratas adultas da linhagem Wistar. A técnica cirúrgica consistiu em laparotomia mediana com identificação do útero bicorno e ressecção de um segmento de $2 \mathrm{~cm}$ do corno uterino direito. Um retalho de $0,25 \mathrm{~cm}^{2}$ foi retirado dessa estrutura e suturado na parede abdominal com a face endometrial voltada para a cavidade peritoneal. As ratas foram divididas aleatoriamente em dois grupos de acordo com o tempo para a reoperação: Grupo $1(n=15)$, reoperado em 30 dias, e Grupo 2 (n=15), em 60 dias. No momento da segunda laparotomia os implantes foram avaliados macroscopicamente, ressecados e encaminhados para análise microscópica com coloração hematoxilina-eosina e imunohistoquímica (HEMA, AE1 e AE2). Resultados: Os implantes se desenvolveram em 83,3 \% do grupo 1 e $71,4 \%$ no Grupo 2. Não houve diferença estatisticamente significativa entre o peso dos animals dos dois grupos. Também não houve diferença estatisticamente significativa no tamanho da área das lesões induzidas: no grupo 1 a média foi 0,37 $\mathrm{cm}^{2}$ e no grupo 2, de 0,25 $\mathrm{cm}^{2}$. Segundo a classificação histológica semi-quantitativa de Keenan (de acordo com a preservação da camada epitelial de endométrio), o grupo 1 teve média de 1,9 e o grupo 2, de 2,4. Conclusão: A técnica utilizada para o desenvolvimento de endometriose em ratas foi satisfatória.
\end{abstract}

Descritores - Endometriose. Ratos. Modelos animais. Endométrio.

\section{REFERENCES}

1. Farquhar C. Endometriosis. BMJ. 2007; 334(7587):249-53.

2. Mounsey AL, Wilgus A, Slawson DC. Diagnosis and management of endometriosis. Am Fam Physician. 2006; 74(4):594-600.

3. Eskenazi B, Warner ML. Epidemiology of endometriosis. Obstet Gynecol Clin North Am. 1997; 24(2):235-58.

4. Laufer MR, Goitein L, Bush M, Cramer DW, Emans SJ. Prevalence of endometriosis in adolescent girls with chronic pelvic pain not responding to conventional therapy. J Pediatr Adolesc Gynecol. 1997; 10(4):199-202.

5. Carter JE. Combined hysteroscopic and laparoscopic findings in patients with chronic pelvic pain. J Am Assoc Gynecol Laparosc. 1994; 2(1):43-7

6. Mahmood TA, Templeton A. Prevalence and genesis of endometriosis. Hum Reprod. 1991; 6(4):544-9.

7. Strathy $\mathrm{JH}$, Molgaard CA, Coulam CB, Melton LJ $3^{\text {rd }}$. Endometriosis and infertility: a laparoscopic study of endometriosis among fertile and infertile women. Fertil Steril. 1982; 38(6):667-72.

8. Verkauf BS. Incidence, symptoms, and signs of endometriosis in fertile and infertile women. J Fla Med Assoc. 1987; 74(9):671-5.

9. Seli E, Berkkanoglu M, Arici A. Pathogenesis of endometriosis. Obstet Gynecol Clin North Am. 2003; 30(1):41-61.

10. Sampson JA. Peritoneal endometriosis due to the menstrual dissemination of endometrial tissue into the peritoneal cavity. Am J Obstet Gynecol.1927; 14(4):422-69.

11. Metzger DA, Haney AF. Etiology of endometriosis. Obstet Gynecol Clin North Am. 1989; 16(1):1-14

12. Ridley $\mathrm{JH}$. The histogenesis of endometriosis: a review of facts and fancies. Obstet Gynecol Surv. 1968; 23(1):1-35

13. Gardner G, Greene RR, Ranney B. The histogenesis of endometriosis; recent contributions. Obstet Gynecol. 1953; 1(6):615-37.

14. Von Recklinghausen F. Adenomyomas and cystadenomas of the wall of the uterus and tube their origin as remnants of the wolffian body. Wien Klin Wochenschr. 1896; 8:530.

15. Russell WW. Aberrant portions of the müllerian duct found in an ovary: ovarian cysts of müllerian origin. Bull John Hopkins Hospital. 1899; 10:8-10

16. Demco L. Mapping the source and character of pain due to endometriosis by patient-assisted laparoscopy. J Am Assoc Gynecol Laparosc. 1998; 5(3):241-5.

17. Koninckx PR, Martin DC. Deep endometriosis: a consequence of infiltration or retraction or possibly adenomyosis externa? Fertil Steril. 1992; 58(5):924-8.

18. Koninckx PR, Oosterlynck D, D'Hooghe T, Meuleman C. Deeply infiltrating endometriosis is a disease whereas mild endometriosis could be considered a non-disease. Ann N Y Acad Sci. 1994; 734:333-41.

19. ACOG Committee on Practice Bulletins-Gynecology. ACOG practice bulletin. Medical management of endometriosis. Number 11,
December 1999 (replaces Technical Bulletin Number 184, September 1993). Clinical management guidelines for obstetriciangynecologists. Int J Gynaecol Obstet. 2000; 71(2):183-96.

20. Amaral VF, Sanson LT, Sepulcri RP. Novas perspectivas no tratamento da endometriose pélvica. Femina. 2006; 34(3):189-96.

21. Schor E, Freitas V, Soares Jr. JM, Simões MJ, Baracat ED. Endometriose: modelo experimental em ratas. Rev Bras Ginecol Obstet. 1999; 21(5):281-4.

22. Hirata T, Osuga $Y$, Yoshino O, Hirota $Y$, Harada M, Takemura $Y$ et al. Development of an experimental model of endometriosis using mice that ubiquitously express green fluorescent protein. Hum Reprod. 2005; 20(8):2092-6.

23. Schenken RS, Asch RH. Surgical induction of endometriosis in the rabbit: effects on fertility and concentrations of peritoneal fluid prostaglandins. Fertil Steril. 1980; 34(6):581-7.

24. Zamah NM, Dodson MG, Stephens LC, Buttram VC Jr, Besch PK, Kaufman RH. Transplantation of normal and ectopic human endometrial tissue into athymic nude mice. Am J Obstet Gynecol. 1984; 149(6):591-7.

25. Bergqvist A, Jeppsson S, Kullander S, Ljungberg O. Human endometrium transplanted into nude mice. Histologic effects of various steroid hormones. Am J Pathol. 1985; 119(2):33644

26. Vernon MW, Wilson EA. Studies on the surgical induction of endometriosis in the rat. Fertil Steril. 1985; 44(5):684-94.

27. Somigliana $E$, Viganò $P$, Rossi $G$, Carinelli $S$, Vignali $M$, PaninaBordignon P. Endometrial ability to implant in ectopic sites can be prevented by interleukin-12 in a murine model of endometriosis. Hum Reprod. 1999; 14(12):2944-50.

28. Bruner KL, Matrisian LM, Rodgers WH, Gorstein F, Osteen KG. Suppression of matrix metalloproteinases inhibits establishment of ectopic lesions by human endometrium in nude mice. J Clin Invest. 1997; 99(12):2851-7.

29. Jones RC. The effect of a luteinizing hormone releasing hormone (LRH) agonist (Wy-40,972), levonorgestrel, danazol and ovariectomy on experimental endometriosis in the rat. Acta Endocrinol. 1984; 106(2):282-8

30. Keenan JA, Williams-Boyce PK, Massey PJ, Chen TT, Caudle MR, Bukovsky A. Regression of endometrial explants in a rat model of endometriosis treated with the immune modulators loxoribine and levamisole. Fertil Steril. 1999; 72(1):135-41.

31. Story L, Kennedy S. Animal studies in endometriosis: a review. ILAR J. $2004 ; 45(2): 132-8$.

32. Nogueira Neto J, Torres OJM, Borges MOR, Coelho TM, Nascimento AGPAC, Nunes Jr JNN, Esteves GL. Modificações do volume e da histologia de focos de endometriose em ratas tratadas com sinvastatina. Rev Bras Ginecol Obstet. 2007; 29(8):396402.

33. Rosa e Silva, JC. Desenvolvimento de um modelo experimental de endometriose em coelha [dissertação]. Ribeirão Preto (SP): Universidade de São Paulo; 2004. 
Received in 12/10/2008

Accepted for publication in 12/12/2008

Conflict of interest: None

Financial source: None

How to cite:

Amaral VF, Dal Lago EA, Kondo W, Souza LCG, Francisco JC.

Development of an experimental model of endometriosis in rats. Rev
Col Bras Cir. [periódico na Internet] 2009; 36(3). Disponível em URL: http://www.scielo.br/rcbc

\section{Correspondence address:}

\section{William Kondo}

E-mail: williamkondo@yahoo.com 